\title{
Kant, Real Possibility, and the Threat of Spinoza
}

\author{
Andrew Chignell \\ Cornell University \\ chignell@cornell.edu
}

In the first part of the paper I reconstruct Kant's proof of the existence of a 'most real being' while also highlighting the theory of modality that motivates Kant's departure from Leibniz's version of the proof. I go on to argue that it is precisely this departure that makes the being that falls out of the pre-critical proof look more like Spinoza's extended natura naturans than an independent, personal creator-God. In the critical period, Kant seems to think that transcendental idealism allows him to avoid this conclusion, but in the last section of the paper I argue that there is still one important version of the Spinozistic threat that remains.

The possibility of things, which can only be regarded as determinations of a single universal possibility, namely of the highest being, proves the existence of the realissimi as a sum total.

Kant, Reflexion 6279, from the mid-1780s (18:545)

Spinozism is the true conclusion of dogmatic metaphysics.

Kant, Reflexion 6050, from the mid-1780s (18:436)

\section{The most real being and the natura naturans}

Kant's book-length attempt in 1763 to provide a demonstrable proof of God's existence is his last great work in dogmatic, speculative metaphysics. ${ }^{1}$ The proof starts from the premiss that 'something is possible', and from there appeals to Leibniz's actualist principle that 'if there is reality in essences or possibles... this reality must be

${ }^{1}$ Der einzig mögliche Beweisgrund zu einer Demonstration des Daseins Gottes [The Only Possible Basis of a Demonstration of the Existence of God, hereafter 'OPB'] is in the second volume of the Akademie edition. Quotations from Kant's works are translated from Kant 1902-, with the two editions of the Critique of Pure Reason cited by the standard [A/B] pagination, and all other works cited by [volume:page]. I have consulted and sometimes used the translations of $O P B$ by Gordon Treash in Kant 1979, and by David Walford in Kant 1992, as well as Paul Guyer and Allen Wood's translation of the first Critique in Kant 1998. 
grounded in something existent and actual'. ${ }^{2}$ Kant departs from Leibniz, however, in arguing that the 'real' and 'positive' predicates of at least some possibilities are grounded not in the content of the thoughts of an actual being - for Leibniz it was the intentional content of the divine mind that played the grounding role $^{3}$ - but rather in its non-intentional properties. Kant's conclusion is that there is a unique necessary being in which these real predicates are co-exemplified. This being is thus the 'most real being', the 'ground of all real possibility', and, according to Kant, the God of classical Western monotheism.

Scant attention is paid to Kant's proof these days. When it is mentioned, it is typically as just another metaphysical wreck abandoned along the road to the critical doctrine that such arguments are at best the source of regulative 'ideas of reason' and at worst dialectical illusions that can seduce us into error. ${ }^{4}$ But closer scrutiny reveals that not all 'ideas of reason' are equal in Kant's eyes; in fact, this proof survives into the 1780 s and 90 s as one that 'can in no way be refuted'. In other words, Kant continues to think that for some people in some circumstances (in particular, metaphysicians seeking a fully complete and systematic account of their subject matter), his pre-critical proof can motivate rational theoretical belief (Glaube) in or acceptance (Annehmung) of a ground of all real possibility, even though it can no longer motivate the highest kind of 'knowledge' (Wissen). Thus in the critical lectures on religion, Kant says that his 1763 proof shows that metaphysicans must 'accept (annehmen) God as an ens realissimum and all the predicates flowing from this concept at least as an undoubted hypothesis for our speculative reason'. ${ }^{6}$ The fact that Kant

2 Monadology $\$ 44$ (Leibniz 1875-1890, 6:614; Leibniz 1989 (hereafter 'AG'), p. 218.) Leibniz’s follower Christian Wolff develops the argument in some detail in Wolff 1720 , $\$ 975$.

3 'God is not only the source of existences, but also that of essences insofar as they are real, that is, or the source of that which is real in possibility. This is because God's understanding is the realm of eternal truths or that of the ideas on which they depend' (Monadology $\$ 43, \mathrm{AG}$, p. 218).

4 There are a couple of important recent exceptions that treat the proof as centrally important for Kant's later work as well. See Fisher and Watkins 1998; Adams 2000; Stang 2010; Boehm forthcoming; and Abaci 2011, Ch. 4.

5 For more on the notion of theoretical 'belief' (Glaube), and propositions about the ens realissimum as objects of it, see Chignell 2007.

6 The full quotation excerpted earlier in this paragraph says that 'this proof can in no way be refuted, because it has its basis in the nature of human reason. For my reason makes it absolutely necessary for me to accept (anzunehmen) a being which is the ground of everything possible, because otherwise I would be unable to realize (erkennen) what in general the 
still thinks so highly of the proof in the critical period indicates that any flaws in it may spell trouble for his later philosophy as well.

In sections 2-4 of the paper, I elaborate the proof in its pre-critical context while also highlighting the distinction between 'logical' and 'real' modality that appears to motivate Kant's departure from Leibniz and Wolff. In section $5 \mathrm{I}$ go on to argue that it is precisely this departure from Leibniz that threatens to push Kant, wittingly or not, into the arms of Spinoza. In other words, although the early Kant may not have realized it, the necessary being that falls out of the pre-critical proof looks more like Spinoza's extended natura naturans than the independent and personal creator-God of Christianity. Interestingly, this is something that Kant's early commentators seem to have noted: F. H. Jacobi claimed both that all purely speculative reasoning leads to Spinozism and that he first realized this when reading Kant's 1763 proof. Abandoning reason in favour of fideistic commitment to a personal deity, for Jacobi, is the only way to avoid the Spinozistic conclusion. H. A. Pistorius, another contemporary, likewise claimed in 1787 to find a full-blown 'deduction of Spinozism' in the variation on the $O P B$ argument that is sketched in the 'Ideal of Pure Reason' chapter of the first Critique (Jacobi 1787; Pistorius 1788).

As it turns out, an excellent way for Kant to incorporate his new logical/real modality distinction into his system and avoid the Spinozist result is to adopt a transcendental idealist conception of space and time. Note that I am not making the (scandalously attractive) revisionist claim that Kant self-consciously became a transcendental idealist in order to avoid Spinozism - though as we will see there are a couple of texts that suggest as much. Rather, my claim is that Kant's ongoing reluctance to abandon his pre-critical theistic proof, together with his other commitments, provided philosophical pressure to deny the transcendental reality of space and time.?

This would be a nice place to end the story. Unfortunately, in section 7 it will become clear that once we adduce some further and, for Kant, hard-to-resist premisses, even transcendental idealism will not be enough to ward off something like Spinoza's natura

possibility of something consists in' (28:1034). See also Reflexion 6279 , from as late as 1788 , in the epigraph above.

7 Pressure also came from Kant's commitments to the (incompatibilist) freedom of the will and to synthetic a priori knowledge of the axioms of space and time. When Kant first argues for the ideality of space and time in the Inaugural Dissertation, and later in the Transcendental Aesthetic, he only explicitly cites the last of these three pressures. 
naturans - again, not as an object of knowledge, but rather as the object of an important kind of firm theoretical belief/acceptance. Thus although Kant ominously warns in a note from the mid-1780s that 'Spinozism is the true conclusion of dogmatic metaphysics' $(R$ $6050,18: 436)$, at the end of the day Spinozism may be the implicit conclusion of Kant's critical metaphysics as well.

\section{The proof as a whole}

\subsection{First stage 8}

It is worth trying to symbolize the first stage of the argument in order to exhibit its logical form as clearly as possible. Let ' $F$ ' stand for any really possible predicate, ${ }^{9}$ and ' $\mathrm{G}_{\mathrm{F}}$ ' stand for the predicate of 'materially grounding something's being $\mathrm{F}$ ' (the notion of material grounding will be explained below). Thus ' $\mathrm{G}_{\mathrm{F}}(r)$ ' expresses the proposition ' $r$ materially grounds the possession of $F$ '. Let the existential quantifier express actual existence, and let the modal operators refer to 'real' modalities. ${ }^{10}$ Then,

(1) $\diamond(\exists x) \mathrm{F} x[$ Premiss]

This is just the claim that a thing's bearing F is really possible. Since we have already stipulated that ' $F$ ' stands in for any arbitrary (really possible) predicate, it would be ontologically stingy not to grant this premiss, at least for the time being.

The second premiss is only slightly more controversial:

$$
\diamond p \rightarrow \square \diamond p\left[\mathrm{~S}_{5} \text { Axiom }\right]
$$

\footnotetext{
${ }^{8}$ Some of the discussion of the first stage draws on Chignell 2009a. In that paper, I also describe at length what Kant means by a 'demonstration' (Demonstration) and why he thinks (as the title of $O P B$ suggests) that this proof does not pass muster. The short story is that Kant follows eighteenth-century rationalist orthodoxy in holding that the concepts involved in a demonstration require complete definitions, and for the sake of concision in this treatise he decides not to go to those lengths (cf. 2:66).

9 I follow Kant here in using 'predicate' (Prädikat) to refer both to the constituent of a concept and to the corresponding property of an object (without taking any particular position on what properties are for Kant). Although Kant mostly uses the term 'predicate' in this indiscriminate way, he also sometimes uses 'Eigenschaft', 'Determination', and 'Bestimmung' to refer to what we would typically call a 'property'.

${ }^{10}$ For more on Kant's views about 'logical' versus 'real' modality, see Greenberg 2008, chs 10-11; Abaci 2011; Chignell 2009a, 2009b, and 2010, as well as Sect. 3 below.
} 
Kant did not have access to later developments in modal logic, of course, so it is difficult to say whether he would accept (2). His negative statement of the proof - 'that whose annulment eradicates all possibility is absolutely necessary' (2:83) - certainly seems to presume (2). For if 'all possibility' (which presumably means each and every possibility) were not necessarily possible, then 'all possibility' could be grounded in the predicates of a contingent being. Kant's refrain throughout $O P B$, however, is that 'all possibility' has to be grounded in a necessary being, and a good way to make sense of this is to ascribe (2) to him.

It follows from (1) and an instance of (2) that

(3) $\square \diamond(\exists x)(\mathrm{F} x)[(1),(2)$, modus ponens]

The next premiss is the most substantive one in the entire proof:

(4) $\square\left[\diamond(\exists x)(\mathrm{F} x) \rightarrow(\exists y)\left(\mathrm{G}_{\mathrm{F}}(y)\right)\right]$ [Grounding Premiss]

This premiss says that, necessarily, if it is possible that some $x$ is $\mathrm{F}$ (relative to the actual world), then there must actually be something that materially grounds $x$ 's being F. I will have more to say about the Grounding Premiss in section 3 below, but for now let me simply note that it can be used, together with the uncontroversial theorem of the weakest system of standard modal logic,

(5) $[\square(p \rightarrow q) \& \square p] \rightarrow \square q$ [theorem of $\mathrm{K}$, and of $\left.\left.\mathrm{S}_{5}\right)\right]^{11}$

to bring us to

(6) $\square(\exists y)\left(\mathrm{G}_{\mathrm{F}}(y)\right)[(3),(4),(5)]$

(6) says that, necessarily, there is something actual that materially grounds the possibility of something's being $F$ - where ' $F$ ', again, stands for any really possible predicate. Proving (6) would be a major accomplishment from the point of view of actualist metaphysics, but it would hardly secure the necessary existence of God. In order to do that, the argument requires a second stage, one which is easier to grasp if we drop the formalism.

\subsection{Second stage}

(7) Maximal positive predicates are really possible [Premiss]

\footnotetext{
${ }^{11}$ The characteristic axiom of $\mathrm{K}$ is the so-called K-schema: $[\square(p \rightarrow q) \rightarrow(\square p \rightarrow \square q)]$. (5) is a logical equivalent of this schema.
} 
Let a maximal predicate be one that has the highest grade - the greatest extensive or intensive magnitude, in Kant's terms - on a continuum of gradable predicates. A positive predicate is one that is (or is logically equivalent to one that is) possessed of some genuine content of its own - that is, content that is not merely a negation of the content of some other predicate. Having a will, for example, is a positive predicate according to Kant, whereas not having a will is not (2:87-8). Being omnipotent, then, is the maximal positive predicate on the continuum of predicates that ascribe power to a subject. ${ }^{12}$

(7) is not uncontroversial: there are debates within philosophical theology over whether predicates like being omnipotent or being omniscient are even coherent. (7) was uncontroversial in Kant's day, however, and he refers casually to maximal predicates as 'perfections' in the 1759 Optimism essay (2:31 and note), and often talks in terms of maximal positive predicates in $O P B$. God, he says there, is the 'most real of all possible beings' because God has the 'highest degree of real properties (den grössten Grad realer Eigenschaften) which could ever inhere in a thing' $(2: 85 ; \mathrm{cf}$. $2: 88)$. I propose simply to grant $(7)$ in order to focus on the aspects of the proof that are of central concern here.

(8) Fundamental predicates are really possible [Premiss]

A fundamental predicate, for Kant and others in the scholasticrationalist tradition, is one that is both positive and unanalysable. Unanalysable predicates are those that cannot be 'constructed' or derived from simpler predicates via operations like negation, disjunction, conjunction, and so forth. This means that all unanalysables will be positive, though not all positives will be unanalysable. Non-fundamental or derivative predicates, on the other hand, are 'given as a consequence through another' and may be either positive or negative. But the analysis has to stop somewhere, and Kant thinks it is obvious that 'the whole of our cognition ultimately resolves itself into unanalysable [predicates]'. Thus being a university is derivative, for example, since it is obviously complex and constructed from

12 The condition says that a positive predicate either has some genuine content that is not a negation of the content of some more fundamental predicate or that it is the logical equivalent of some such predicate. Thus the predicate not being limited in power-which involves a negation - still counts as a positive predicate by way of being the logical equivalent of the predicate being omnipotent. That said, Kant is not very explicit about how he conceives of the logical features of predicates, and thus it is not clear that the positive or fundamental status of a predicate can be demonstrated in wholly non-circular ways. Thanks to an anonymous referee for pointing out the complications here. 
simpler predicates, whereas having a will is fundamental for Kant. Clearly not all of the fundamental predicates admit of maximal degrees or grades, however, and so they will also need (in light of (4)) to be 'given as a determination in the actual' if something possessing them and/or any predicates derived from them are really possible $(2: 79,88)$. The premiss that we need in order to take care of both kinds of cases is thus:

(9) Necessarily, if something is the material ground of either a maximal positive predicate or a non-gradable fundamental predicate, then it actually exemplifies that predicate

This premiss, like the Grounding Premiss from which it stems, is one of the central components of Kant's proof. I will examine it in more detail in section 4 below. It follows from what we have so far that

(10) Necessarily, every really possible maximal positive predicate and every really possible non-gradable fundamental predicate is exemplified by some actual being [(6)-(9)]

Kant goes on to argue that the maximal predicates and the fundamental predicates are materially grounded in the same unique being - he calls it the ens realissimum (i.e. 'most real being'; henceforth ' $E R$ ') and that this being is a necessary, immutable, eternal, personal God. I will simply list these premisses here, and save further discussion of them for section 6 .

(11) Necessarily, for all $x$, there is a unique being such that $x=E R$, where $E R$ exemplifies every really possible maximal positive predicate and every really possible non-gradable fundamental predicate [(10), sub-argument in Section 4 below]

(12) ER exists necessarily [(11), sub-argument in Section 4 below]

(13) Necessarily, ER is immutable and eternal [(11), being immutable and being eternal as maximal positive predicates]

(14) Necessarily, ER has an intellect and a will [(11), having an intellect and having $a$ will as non-gradable fundamental predicates]

(15) Necessarily, ER is divine (and thus: God necessarily exists) [(11)-(14), Kant's conception of 'God'] 
That is the proof as a whole. Here I will only quickly rehearse the first stage before turning to the second, almost every premiss of which is controversial. My main goal is not to defend or even fully explicate the entire proof, though I do hope to give it a run for its money. Rather, the main goal is to show how the reasoning it contains leads Kant to first one and then another confrontation with Spinoza.

\section{The first stage: a material ground of possibility}

\subsection{The Grounding Premiss}

The central premiss of the first stage of the proof is

(4) $\square\left[\diamond(\exists x)(\mathrm{F} x) \rightarrow(\exists y)\left(\mathrm{G}_{\mathrm{F}}(y)\right)\right]$ [Grounding Premiss]

Again, (4) says that, necessarily, if it is possible for some being to exemplify $\mathrm{F}$, then a being exists in the world with respect to which that is possible, and the latter being materially grounds the possible exemplification of F. The two beings (i.e. $x$ and $y$ ) might be identical, but often they will not be, since Kant explicitly says that $x$ might also be merely possible and not actual.

From a textual point of view, Kant's commitment to the Grounding Premiss is indisputable: 'all possibility in sum and each possibility in particular presuppose (voraussetzen) something actual, be it one thing or many' (2:79). Sometimes he formulates this principle negatively: 'That [state of affairs] through which all possibility is altogether cancelled (aufgehoben) is absolutely impossible' or, in a passage cited earlier, 'that whose annulment eradicates (vertilgt) all possibility is absolutely necessary' $(2: 79,83) .^{13}$

So Kant accepts (4). But how does he defend it? The notion of an explanatory requirement or 'presupposition' (Voraussetzung) plays an important role here and it, like the proof as a whole, is rooted in German rationalism. Leibniz claims that the availability or 'givenness' of a thing's predicates is an explanatory presupposition of its being both possible and actual, whereas God's decision to create the thing is a causal condition of its being actual. The first condition is obviously

\footnotetext{
${ }^{13}$ Despite these different formulations, the principle here is really the strong one we find at 2:79 according to which a being whose non-existence eradicates any real possibility has to exist. In other words, if a grounding being is required for all real possibilities taken collectively, then that is because a grounding being is required for any real possibility taken individually. I will discuss in more detail later why Kant thinks that the same unique being must ground all real possibilities.
} 
logically prior to the second: the predicates of things must be 'given' somehow in logical/metaphysical space in order for God to survey all possible combinations of them and actualize the world of individuals that is the best. Leibniz follows Augustine in holding that this 'given' is located in the divine ideas themselves, and thus his quasi-cosmological argument from possibility proves that there is a necessary being that somehow represents all possible essences, as well as all of their possible combinations (in the form of what Leibniz calls 'worlds'). ${ }^{14}$

The early Kant goes along with Leibniz on much of this. He too thinks that the conditions on existence include having an explanatory ground (Grund, ratio) and having an actual cause (Ursache, causa), while the conditions on mere possibility are explanatory but not necessarily causal (see e.g. Nova Dilucidatio 1:392-4). Kant also agrees that there are both 'real' and 'logical' explanatory conditions on possibility. In $O P B$, he puts the point this way: 'in every possibility there must be distinguished the thing which is thought and the agreement of that which is thought in it with the principle of contradiction' (2:77, my emphases). In the next section, I will consider Kant's account of these in reverse order before turning to a discussion of the point on which Kant makes the crucial break with Leibniz.

\subsection{Three conditions on possibility}

The main condition on logical possibility for early modern metaphysics is

(Consistency) The predicates of a thing must be logically consistent with one another

In other words, the predicates of a thing must be such that no conjunction of two or more of them is logically equivalent - using standard first-order rules - to a contradiction. If (Consistency) is not satisfied, then the being in question is not only really impossible but also logically impossible. This condition, I suspect, is more or less unobjectionable.

The 'material' conditions of possibility, according to Kant, are two in number. First, the 'content' of a thing must be 'given as data' and 'available for use' (2:77-2:78). In other words, the thing in question

${ }^{14}$ See Leibniz 1875-1890, 7:305: '[N]either those essences nor the so-called eternal truths pertaining to them are fictitious; rather, they exist in a certain region of ideas, so to speak, in God himself, the source [fonte] of every essence and of the existence of the rest'. Thanks to Sam Newlands for pointing me to this passage. 
must have some positive predicates whose content determines its existence in one way rather than another. ${ }^{15}$ That might be true for logical possibility as well (clearly the predicates must have some content or other) but the condition here is that those positive predicates are also really possible - that is, that they are 'given as data' in metaphysical space. Kant anticipated this picture already in the Nova Dilucidatio: positive predicates must be 'real' and 'available for use by thought', he says there, in order for them to figure into 'any concept you please of a thinkable thing'. If they are not somehow given, or if they do not have genuine determining content, then the thing in question may be logically possible but still really impossible (1:395-6). In other words, it may be the object of a concept whose key predicates are logically consistent but still, in Kant's technical terminology, 'empty'.

By way of example, consider a concept that only contains predicates that fail to pick out genuine properties - for example, being such that $2+2=4$ - as well as various negative predicates - not being a horse, not being Sherlock Holmes - and perhaps some highly indeterminate relational or disjunctive predicates - existing at $t_{1}$, or $t_{2}$, or $t_{3}$, or $t_{4}$, or ... $t_{n}$. Such a concept is too empty, in Kant's view, to pick out a genuine possibility. But strange concepts like these are not the only empty ones, of course; in the first Critique Kant repeatedly accuses the rationalists of trafficking in empty concepts of mere 'thought-entities' (Gedankenwesen), ${ }^{16}$ and in the third Critique he worries that even the familiar concept of a final end is 'merely a rationalistic (vernünftelnder) and objectively empty concept' (5:396). The condition, then, seems to be something like this:

(Content) The positive predicates of a thing must be given in such a way that they possess 'real' content

Despite Kant's anti-rationalist rhetoric here, he and Leibniz agree on most of the essentials thus far: if a thing is possible, then there cannot

15 'Every characteristic mark (Merkmal) which is to be found in [real things] is positive' (Optimism 2:31). See also Nova Dilucidatio 1:395-6, 'Negative Magnitudes' 2:47, and OPB 2:87ff. The case of relational predicates is complicated - some are 'positive' in the technical sense, for Kant, and some are not. I will focus here on predicates which clearly do positively determine an object.

${ }^{16}$ Kant criticizes 'the famous Leibniz' in the first Critique for missing the fact that 'the connection of all real properties in a thing is a synthesis about whose possibility we cannot judge a priori because those realities are not given to us specifically'. As a result, Kant concludes that, with respect to God, 'Leibniz was far from having achieved what he flattered himself he had done, namely, gaining insight a priori into the [real] possibility of such a sublime ideal being' (A602/B630). 
be logical inconsistencies in its concept, and it must possess positive predicates with real, given 'data' as content. Kant will also add here that the predicates' content must be such that an object's possessing it is really possible. Again, Leibniz holds that the positive predicates are given in the divine representations of essences; thus he can say that the being though not the truth of the necessary truths about essences is grounded in God's thoughts. ${ }^{17}$ It is at this point that Kant makes a significant break with the tradition: in reflecting on the distinction between logical and real modality - a distinction which he frequently accuses Leibniz of blurring - Kant sees that a concept may contain logically consistent as well as positive, given predicates and yet still fail to pick out a real possibility. That is because the positive, contentful predicates can fail to be really harmonious with one another. As Kant writes in a note a few years later: ' $[\mathrm{N}]$ ot every concept in which there is no contradiction is a possible synthesis - that is, real relations are not seen through the principle of contradiction' (17:382). ${ }^{18}$ The opposite of real harmony - 'real repugnance' (Realrepugnanz) — is what 'obtains anytime something, as a ground, obliterates the consequence of another in a genuine conflict (Entgegensetzung)' (2:86).

Kant offers a number of different examples of real repugnance in $O P B$ and the 'Negative Magnitudes' essay of the same year, and his arguments on that score foreshadow not only a significant break with the Leibnizean tradition, but also a major innovation in his own thinking. Many of the examples involve what might be called predicate-cancelling real repugnance. These are cases in which two opposed physical forces - Kant often thinks of opposing winds, or magnetic impulses - 'cancel' one another and leave the body that exemplifies them both at rest. More important for our discussion, however, is what I will call subject-cancelling real repugnance. Such repugnance involves two or more positive predicates 'cancelling' not merely their respective effects on the subject, but also the subject itself

\footnotetext{
${ }_{17}$ Again, see Monadology $\$ 43-4$ (AG 218). In the critical period, Kant disagrees with Leibniz about what is involved in making sure that the content of the concept is 'given', and argues that establishing a connection to possible intuition is almost always required. Thus in his anti-Leibnizean tract 'On a Discovery', Kant defines an 'absolutely empty' concept as one to which 'no corresponding intuition can be given' (8:214, my emphasis). This later disagreement should not obscure the fact that Kant is following Leibniz in holding that the 'givenness' of conceptual content is a condition on possibility.

${ }^{18}$ This is Reflexion 4004 from 1769. Thanks to Uygar Abaci for calling this passage to my attention.
} 
qua real possibility $(2: 190-4){ }^{19}$ This sort of relation is familiar in contemporary metaphysics; it is akin to the non-logical repugnance that is supposed to hold between predicates like being water and being $X Y Z$, where ' $X Y Z$ ' refers to something other than ' $\mathrm{H}_{2} \mathrm{O}$ ', or between being Cliff Richard and being born to Bill and Hillary Clinton. ${ }^{20}$ Kant's own examples in $O P B$ include that 'the impenetrability of bodies, extension and the like, cannot be attributes of what has understanding and will'. It is not that being extended and having a mind are logically inconsistent, for Kant: there is no way to generate a contradiction from their conjunction using standard rules and definitions. Rather, it is that 'these predicates can by no means co-exist together as determinations in a single subject' (2:85). The 'cannot' and 'can' in these sentences refer to real modalities: a subject that is both extended and has a mind cannot really be. We see this all the way into the critical period: 'it is impossible to conceive a matter endowed with thought' (Religion 6:128-9, note).

Another example of subject-cancelling real repugnance can be developed from Kant's $O P B$ discussion of a 'Supreme Being' with the positive predicate emanating the universe. The problem is that the latter predicate somehow entails the 'deprivation or lack' (Beraubung oder Mangel) of understanding and will. Kant is clearly thinking of Spinoza's philosophy here: this is how he often, though controversially, describes the natura naturans (cf. 5:393-4). Such a being is logically but not really possible, Kant then suggests, because only a divine being could emanate the universe, and yet its lack of will and understanding render 'its essence far inferior to what one must think when one thinks of a God' (2:89). Thus any subject with the derivative predicate emanating the universe is 'cancelled' in virtue of the real repugnance contained within it.

\footnotetext{
19 In the 'Negative Magnitudes' essay of 1762, Kant describes the 'cancellation' (Aufhebung) of the entire subject that results from real repugnance between two of its predicates: ' $[\mathrm{F}]$ or something positive which exists to be cancelled, it is just as necessary that there should be a true real ground as it is necessary that a true real ground should exist in order to bring it into existence when it does not already exist... Supposing that $a$ is posited, then only $a-a=0$. In other words, only insofar as an equal but opposed real ground is combined with the ground of $a$ is it possible for $a$ to be cancelled (kann a aufgehoben werden)' (2:190).

${ }^{20}$ Some philosophers in the post-Kripke/Putnam era have sought to locate the origin of the impossibility of such states of affairs in semantic facts (e.g. David Chalmers and Frank Jackson). But there are many contemporary philosophers, including Kripke himself on most interpretations, who base this sort of repugnance in metaphysical facts about natures. See the essays in Gendler and Hawthorne 2002 for the details of this debate.
} 
These examples could do with further elaboration, but they at least indicate how the early Kant aims to supplement Leibniz's list of the conditions on possibility. A really possible thing's predicates will not only satisfy (Consistency) and (Content); they will also lack subjectcancelling real repugnance. Or, put positively,

(Harmony) The predicates of a thing must be really harmonious with one another

where being really harmonious entails the lack of any subjectcancelling real repugnance. In what follows, I will use 'real repugnance' to refer to the subject-cancelling sort unless otherwise noted, and 'real harmony' to refer to the lack of that sort of repugnance.

Having briefly surveyed these three necessary conditions on real possibility, we can finally ask what it would mean for something to satisfy them. What further conditions, if any, are there on the satisfaction of these three conditions? And how does all of this relate to the Grounding Premiss?

Kant does not think there is much to be said by way of explaining what it is to satisfy (Consistency): if two or more predicates satisfy this condition, it will be a necessary truth that they do so (i.e. it will be necessary that their conjunction is not logically equivalent to a contradiction.) That is all the explanation that is required, even for a rationalistic thinker.

The satisfaction of (Content) requires more than this, but it can still occur without supposing that the predicates of the thing in question have an actual instance. With respect to derivative predicates, (Content) is satisfied just in case there is the right kind of positive content in the fundamental predicates out of which the derivatives are constructed. With respect to fundamental predicates, the consensus in the rationalist tradition (again, following the Augustinian scholastic tradition) was that some mind or other is required to represent these predicates - thereby 'giving' them with real content that is then 'available for use' in the construction of concepts of individuals. According to Leibniz, for instance, God can think extension without himself being extended, and that is sufficient for extended possibilia to satisfy (Content), other things being equal. ${ }^{21}$

${ }^{21}$ Again, from Monadology $\$ 43$ : 'It is true that God is not only the source of existences, but also that of essences insofar as they are real, that is, or the source of that which is real in possibility. This is because God's understanding is the realm of eternal truths or that of the ideas on which they depend; without Him there would be nothing real in possibles, and not 
But what explains the fact that (Harmony) is met by a possible being? The claim that its predicates are thought together by God or any other mind is not going to be sufficient here, since thought, by Kant's own definition, tracks logical rather than real possibility (more on this in Sect. 8 below). But his pre-critical commitment to a moderate kind of rationalism will not allow him to leave the satisfaction of (Harmony) as a brute fact either. On the contrary, the metaphysical harmony between two or more predicates itself requires explanation, and for Kant the only way to explain such a fact is to appeal to the actual exemplification of these predicates together in some actual being (along with the trivial principle that actuality entails possibility). Kant clearly has a kind of regressive, transcendental argument in mind: in effect he is seeking the conditions of the possibility of real possibility itself.

It is this complex line of thought, then, that leads to the Grounding Premiss in (4): 'All possibility presupposes something actual in which and through which everything [really possible] is given' (2:83). That actual existence of a thing with that combination of predicates grounds the positive predicates in terms of their content and in terms of their mutual harmony. This is the best kind of grounding a predicate can have, and it is what I have been calling 'material grounding' above: something that is materially grounded satisfies both (Content) and (Harmony).

In summary, a thing is materially grounded with respect to its derivative predicates by appeal to the fundamental predicates out of which the derivative predicates are constructed..$^{22}$ But with respect to its fundamental predicates, (Harmony) can only be met by some actual instantiation of those very predicates - they must be 'given as a determination in the actual' $(2: 79,88)$. Moreover, if it is a necessary truth that the predicates in question can be instantiated together, then it will be a necessary truth that a material ground of their harmony that is, a being that exemplifies the predicates together-actually exists. And that is what (6) is meant to say.

only would nothing exist, but also nothing would be possible' (AG 218). See also Theodicy $\$ 184-9$.

${ }^{22}$ Note that this means that the proof up through (6) works for non-fundamental predicates too. It is just that the actual $y$ that materially grounds the ascription of those predicates to some $x$ can be the same $y$ that materially grounds the fundamental predicates from which the non-fundamental predicates are constructed. This allows us to leave ' $F$ ' in the proof unrestricted (i.e. ' $\mathrm{F}$ ' does not just stand for any fundamental really possible predicate; rather, it stands for any really possible predicate whatsoever). 


\section{The second stage: the unique ground of all perfections}

With (6) in hand, Kant seems to think that the traditional God's existence is within striking distance: he spends a remarkably small portion of $O P B$ racing through to his ultimate conclusion that God conceived as the ens realissimum necessarily exists. In fact, however, there are serious problems lurking here; in what follows, I will focus primarily on the ones that generate the threat of Spinoza in $O P B$ and beyond.

Kant believes that the ground of real possibility is not only an ens realissimum but also an ens perfectissimum: 'those same determinations through which this being is the ultimate ground of all possible reality presuppose in it the maximum degree of real predicates that can ever belong to a thing' (2:85). This makes it clear that Kant is committed to the claim that there is a unique material ground of possibility - a claim that will be discussed in the context of (11) below. For now, however, let us consider the other idea that is motivating Kant in the passage just quoted, namely:

(9) Necessarily, if something is the material ground of either a maximal positive predicate or a non-gradable fundamental predicate, then it actually exemplifies that predicate [Premiss]

(9) implies that the real possibility of an omniscient being must be grounded in the actual existence of a being that has not only some knowledge but all knowledge. But why think (9) is true? The answer can be found in Kant's doctrine that there is a quantitative degree or 'magnitude' in many qualitative predicates, ${ }^{23}$ and that the real possibility of that degree or magnitude must itself be materially grounded. Thus the real possibility of the greatest degree of knowledge must be grounded in a being who exemplifies the greatest degree of knowledge.

But, an objector might continue, why think that is true either? Why not simply allow that an actual being that has at least some knowledge can be the material ground of the possibility of omniscience? The principle underlying all of this, I submit, is the rationalist one according to which (in Kant's own words) 'there is nothing in that which is explained (in rationato) which is not in the explanans itself' (1:407).

\footnotetext{
23 This doctrine shows up again in the Axioms of Intuition and Anticipation of Perception in the first Critique; Kant argues there that many predicates have both an extensive and an intensive grade (Grad) or 'magnitude' (Grösse).
} 
Readers of the Third Meditation will recall Descartes's principle that an effect can only have as much formal or objective reality as its cause has formal reality, and that he uses this principle to prove God's existence. Kant similarly holds that even if the explanandum is merely really possible, the explanans must have at least as high a degree of 'magnitude' as the explanandum in order to do its explanatory work. He also agrees with Descartes that these principles apply not only to straightforward causal relations in the actual world, but also to grounding relations that hold across modes of being (formal/ objective, actual/possible). For Kant, then, the actual instantiation of a predicate like being somewhat knowledgeable could not materially ground the real possibility of something's being omniscient, since the magnitude or degree of the latter predicate must also be grounded or explained. Other things being equal, omniscience is really possible if and only if it is actual. ${ }^{24}$

Even granting this interpretation, however, we still might want to know how Kant proposes to defend the rationalist principle in question. My own view is that it stems from a modal application of the principle of sufficient reason (PSR) itself - the principle that, as Kant puts it in the Nova Dilucidatio, 'nothing is true without a determining ground' (1:393). Note that 'ground-consequence' (GrundFolge) for Kant is a dependence relation that is broader than mere cause-effect and in fact encompasses it: a non-causal relation of explanans-explanandum, for example, would also be an instance of ground-consequence dependence. If an explanatory consequence were to have more magnitude than its ground, there would have to be a further, additional explanation for the additional magnitude. But if it were not located in the ground, then it is not clear what or where the explanation could be. The principle of determining ground (i.e. Kant's version of the PSR) prohibits such brute facts, and so it looks like the being or beings that play the grounding role with respect to gradable predicates must exemplify the maximal versions of them. And the actual exemplification of a maximal version of a gradable

\footnotetext{
${ }^{24}$ Compare Aquinas's Fourth Way: 'But what is called maximally such in any kind is the ground of all that are of that kind, as fire, which is maximally hot, is the ground of all hot things [being hot] ... Therefore there is something that is the ground of being to all beings, and of goodness and whatever perfection; and this we call God' (Aquinas 1265-74, ST I, q.2, a.3). The argument in Thomas is of course restricted to ground-consequence relations between actualia. But the impulse behind it is the same as the impulse motivating Kant.
} 
predicate is then supposed to be able to ground the real possibility of all less-than-maximal grades of it. ${ }^{25}$

It may be that the rationalist principle under discussion - that there can be nothing in the (possible) consequence that is not already in some way found in the (actual) ground - can be derived from something weaker than the PSR. Perhaps it could just come from the ex nihilo principle that nothing comes from nothing, and perhaps that principle can be grounded in something weaker than the PSR itself - indeed, Descartes seems to take this route in the Third Meditation. I will not go into this issue here, since the pre-critical Kant is clearly a devotee of some version of the PSR. He provides a demonstration of an unrestricted version of it in the Nova Dilucidatio of 1755 , and in $O P B$ he says that he is still willing to 'subscribe' (unterschreiben) to it in most contexts (2:158). In the critical period, moreover, he allows that the non-empirical principle of 'ground-consequence' can lead speculative metaphysicians not to knowledge but still to rational, theoretical belief (Glaube) about supersensibles (A783/ B811). ${ }^{26}$

The above argument for (9), together with the controversial claim in (7) that some maximal predicates are really possible and the

\footnotetext{
${ }^{25}$ Kant puts the argument (applied specifically to the 'personal' predicates of understanding and will) in the form of a reductio: 'Given that understanding and will are properties (Eigenschaften) which are capable of the highest degree of reality but, nonetheless, are to be counted among the merely possible properties, it would follow that understanding and will, and all reality of the nature of mind, would have to be possible in others through the necessary being as a ground, even though they would not be found as determinations (Bestimmungen) in the necessary being itself. The consequence would accordingly be greater than the ground itself... Now since the consequence cannot exceed the ground, understanding and will must inhere in the necessary simple substance as properties' (2:88).

${ }^{26}$ The passage from the Critique here is one in which Kant can actually seem to denigrate the PSR: he says it cannot be proved, and thus that its 'power to prove' (Beweiskraft) is limited (see also 8:213n). But Kant ultimately suggests that although the 'experts' agree that no one has succeeded in providing a full proof (Beweis) of the PSR, it is still ungiveupable (da man diesen Grundsatz doch nicht verlassen konnte), and so until 'transcendental critique came onto the scene' the indifferentists and common sense philosophers were left making haphazard appeals to 'healthy human understanding' to motivate their speculative inferences. Like them, Kant wants to resist the claim that the PSR admits of full-blown proof, but he does think transcendental philosophy allows various speculative, explanatory principles to play a crucial role in the construction of non-epistemic attitudes like belief (Glaube). Consider also the following Reflexion: 'The principle of the self-preservation (Selbsterhaltung) of reason is the basis of rational belief, in which assent has the same degree as knowledge (das Fürwahrhalten eben den Grad hat als beym Wissen), but is of another kind which comes not from the cognition of grounds in the object but rather from the true needs of the subject in respect to theoretical as well as practical applications' (16:371-2). Thanks to Kenneth Winkler for helpful discussion of these passages.
} 
assumption that there can be nothing in the explanandum that is not in the explanans, lead us to

(10) Necessarily, every really possible maximal positive predicate and every really possible non-gradable fundamental predicate is exemplified by some actual being [(6)-(9)]

Clearly the next thing for a monotheist to prove is that a plurality of beings is either inadequate to the overall grounding task, or in any case otiose and thus vulnerable to Ockham's razor. Surprisingly, however, Kant does not provide arguments along either of those lines for the following premiss:

(11) Necessarily, for all $x$, there is a unique being such that $x=E R$, where $E R$ exemplifies every really possible maximal positive predicate and every really possible non-gradable fundamental predicate [(10) and sub-argument below]

Instead, he skips ahead and argues from the de re necessity of a material ground to its uniqueness. But his arguments on that score seem rather dubious ${ }^{27}$ and in any case we have not arrived at the de re

27 Here is the main argument:

Suppose that A is a necessary being and B another. Now by definition B is possible only insofar as it is given through another ground, A, as a consequence of A. But since, according to the assumption, B itself is necessary, its possibility is in itself as a predicate and not as the consequence of another. Yet the preceding maintains it is only as a consequence that it is given, and this is self-contradictory. (2:84)

Kant is relying here on the assumption that 'any necessary being contains the ultimate ground of the possibility of all other beings'. So if A is indeed necessary, then the possibility of all other beings, including B, must be grounded in A. But then B, 'which is itself dependent, does not contain the ultimate ground of all possibility, and is accordingly not absolutely necessary'. Kant's conclusion is that 'several things cannot be absolutely necessary' (2:84).

But all of this seems question-begging. Why should we grant the assumption that any necessary being is the ground of the possibility of all other beings? Why could A not be a necessary being that grounds some of the real possibilities, and B be a necessary being that grounds the rest of them? In that case both beings would be required by the argument in (1)-(10).

In Nova Dilucidatio, Kant offers yet another argument for the uniqueness of the necessary being. His thought there is that 'absolute necessity is not compatible with deprivations as it is with realities' (1:395). In other words, a necessary being cannot have limitations; it can only have 'realities' in their maximal degree (including, of course, the maximal predicate of omnipotence). But why could one of Hume's mediocre deities not be necessary? Perhaps Kant thinks that there would have to be an explanation, in accordance with the PSR, of why the being's predicates are limited in just the ways that they are, and that this explanation would appeal to some other being (since the fact in question cannot just be brute). Thus the first being's character would be dependent in some way on the second being. But simply to stipulate that both beings cannot be necessary is to beg the question at hand: we are trying to determine whether two or more beings can be necessary (and thus collectively play the role 
necessity of the grounding being(s) yet. I will argue later that the best argument for the latter presupposes that the being is unique, and thus presupposes the truth of (11). ${ }^{28}$ But if that is right, then we need to find some independent support for (11).

Perhaps we can locate such support in the following argument. Note that (9) says that the being that serves as the ground of the predicate being omnipotent itself has to be omnipotent. And recall that in traditional philosophical theology, the logic of the predicate of omnipotence is taken to entail that no more than one actual being exemplifies it. Two beings could, in Manichean fashion, have extremely great power, but it is impossible for two beings to be allpowerful.

Even if this is correct, however, it does not get us very far. For even granting that there cannot be two omnipotent beings, Kant's argument leaves it open that there is an omnipotent being that materially grounds the predicate being omnipotent and perhaps all the other predicates ascribing power, but still does not ground a number of other real possibilities. What if this omnipotent being happens to be a rather nasty character, for instance-one of Hume's 'mediocre deities'? Then there would have to be yet another being that grounds the real possibility of the maximal predicate being omnibenevolent, but that being would not need to be omnipotent. On this scenario, a committee of mediocre deities (however unpleasant the thought) might manage collectively to ground all real possibilities.

A prominent line of response to this sort of objection says that the possession of omnipotence somehow entails the possession of the other perfections. Descartes suggests this in his reply to Caterus: it follows from the concept of a 'supremely powerful being', he says, that it 'cannot but possess within it all the other perfections that are contained in the idea of God'. Descartes claims to be able to perceive that this is true despite the fact that 'our mind, which is finite, normally

\footnotetext{
of the ground of all material reality), whereas this argument simply assumes that there could not be two mutually dependent and thus collectively necessary beings.

${ }^{28}$ In his discussion of the proof in the critical lectures on religion Kant says only that from the very 'concept of a being having all reality' it follows that it 'can only be singularis'. He also remarks that 'common sense teaches monotheism by taking as its supreme principle a being which is all in all'. The appeal to common sense is not philosophically fleshed out, and I am not sure that much can be made of it. However, the remark may help explain why Kant seems unconcerned to find a strong argument for (11). See Lectures on the Philosophical Doctrine of Religion 28:1040.
} 
thinks of these perfections only separately, and hence may not immediately notice the necessity of their being joined together' (Descartes 1641; Adam and Tannery 1996 (henceforth 'AT') 7:119; Cottingham, Stoothoff, and Murdoch 1984 (henceforth 'CSM') 2:84-5). In a lecture from the critical period, Kant seems to follow Descartes and the 'scholastic theologians': with respect to perfections, he writes,

I think of each such unlimited reality equally as a ground from which I understand every other unlimited reality. For example, when I represent omniscience, I equally regard it as a ground through which I posit omniscience, omnipotence, etc., and I rightly infer that the being to which this single reality belongs without limitation is a being to which all the other realities also belong; and hence arises the concept of God. (28:1015)

In order to evaluate the main point here, let us start with Kant's own example of being omniscient. The idea is that having this perfection is equivalent to having a certain power or ability — roughly, the ability to know every true proposition. Similarly, the perfection of being omnipresent is equivalent to having the power to effect changes in any or every place at once. (Note that this provides a hint about how God could be said to have all these conceptually distinct perfections and still be metaphysically 'simple'.) If this is right, then Descartes and Kant would be justified in thinking that an omnipotent being would also have to be omniscient and omnipresent.

But even granting all of this, it is still very hard to see how the same thing could be said of an axiological perfection like being omnibenevolent. For benevolence or moral goodness clearly is not wholly constituted by a set of powers. Of course, an omnipotent being could perform all of the actions that a perfectly morally good being performs, but it seems that being morally good also involves (at least!) a positive inclination towards performing these actions. Unless we subscribe to the Socratic notion that to know the good is to will it which Kant, given his conception of 'radical evil', is not going to do - it is unclear how the axiological perfections can be entailed by omnipotence or omniscience. ${ }^{29}$

Various non-axiological predicates present an analogous problem. Consider various qualities of consciousness like being in pain, seeing red, or experiencing fear. These are clearly possible, and contemporary

29 There may be an analogous gap in the case of omniscience. Being all-powerful ensures that God has the power to know all true propositions, but does it entail that he will actually exercise that power? One can imagine an anti-intellectual omnipotent being, perhaps, who can know everything, but simply does not bother to do so. 
philosophers will be tempted to view them as fundamental in Kant's sense, though admittedly the eighteenth-century rationalist tradition does not speak with one voice here..$^{30}$ And yet it is not at all clear that an omnipotent being, qua omnipotent, would have to exemplify really possible predicates like those just mentioned, nor is it clear that such a being would choose to exemplify them. This is all the more true for their maximal counterparts being in maximal pain and experiencing maximal fear..$^{31}$ So even if an advocate of the proof could somehow deal with the objections just raised about axiological perfections, the variety and richness of the possible predicates that need materially grounding might still pose a problem for the uniqueness claim in (11).

There is still one component of Kant's account in $O P B$, however, that may have more success in this connection. Recall from section 3.2 above that the fundamental predicates of a really possible subject must possess 'real' or 'positive' content. We have seen that this (Content) condition alone does not require that the material ground of real possibility be a unique being - a committee of beings could still do the job. But Kant also thinks (and, again, this is one of his great innovations over Leibniz) that a real possibility's predicates have to enjoy real harmony amongst themselves, and that this in turn means that no two of them can be really repugnant in a subject-cancelling way. My sense is that an appeal to (Harmony) can provide crucial support needed for (11).

In order to see this, consider a being whose predicates include having phenomenal red as a quality of consciousness and being

${ }^{30}$ In 'Negative Magnitudes', Kant claims that neither positive pleasure nor positive displeasure (pain) can have their real possibility grounded in God (2:201). It is not clear where they do find a material ground, however. Leibniz and Eckhard conducted an interesting discussion of whether God can feel pain, but in letters to which Kant would not have had access. Leibniz concludes 'with some scruples' that although pain is a positive predicate and not a mere privation, it is a less perfect one than pleasure, and thus that God need only possess the latter (Leibniz 1969, p. 177). This leaves it unclear how, for Leibniz, the real positive content of a predicate like being in pain will be grounded, given that it is not merely the privation of having pleasure. Elsewhere, Leibniz's position seems to be that pain and pleasure are both 'confused' representational states and thus not fundamental at all.

\footnotetext{
${ }^{31}$ Would exemplification of these predicates be entailed by the being's omniscience? Philosophers attracted to a certain position in the contemporary qualia debates might think that, in order to be omniscient, the being would have to know what it is like to fear the future, and that this means that it would have to fear the future. The problem is that this line of argument would result in lots of undesirable predicates being attributed to the ens perfectissimum — predicates like 'being weak of will' or 'being morally repugnant' - since omniscience would also involve knowing what having these predicates is like. So there must be some other, less direct way for the omniscient being to get the relevant kinds of 'what it is like' knowledge (provided there is such knowledge). If there is not, then this might be yet another route to the kind of overly fecund deity that Kant presumably wants to avoid.
} 
omnibenevolent. Let us grant that the first is a non-gradable fundamental predicate, that the second is a maximal predicate, and that the being as a whole is really possible. In order for this to hold, the predicates must be logically consistent and have positive content. But since the possibility in question exemplifies both of them at the same time, they must also be materially harmonious. Moreover, this latter fact that the predicates are harmonious - also has to be explained: given the logical/real modality distinction and the threat of real repugnance, it is not something that we can legitimately just presume about omnibenevolence and seeing red. ${ }^{32}$ Kant's argument above seems to entail that only the actual exemplification of these predicates together in a single being can do the job of satisfying the (Harmony) condition. Thus an actual, single being that exemplifies both having phenomenal red as a quality of consciousness and being omnibenevolent is necessary (and sufficient) to ground the real possibility in question.

The argument can also be run the other way round. Consider a single substance with the predicates being conscious and being extended. Such a substance, of course, is not really possible according to the early Kant. But why? The explanation of this cannot be that there is no being that grounds the positive content of these predicates, since Kant thinks that God is such a being. Rather, a conscious extended being is really impossible because there is nothing that grounds the real harmony of these two predicates by way of exemplifying both of them together. God, recall, grounds extension by exemplifying various powers, at least on Kant's considered view (see Sect. 5).

A generalized form of the argument can be given for all combinatorial real possibilities: if an object bearing fundamental or maximal predicates $\mathrm{F}$ and $\mathrm{G}$ is really possible, then there must be some actual being that grounds the positive content of $F$ and $G$ and one that grounds their material or real harmony. This means that two distinct beings - one bearing $\mathrm{F}$ and one bearing $\mathrm{G}$ - will not be able to play the grounding role. For although these two beings could ground the content of $\mathrm{F}$ and $\mathrm{G}$ distributively, they would not be able to ground the harmony between F and G; only a single being that is at once both $\mathrm{F}$ and $\mathrm{G}$ could do that. And thus, mutatis mutandum, only a unique

${ }^{32}$ Leibniz claims that all fundamental predicates are compossible in his defence of the ontological argument (cf. Leibniz 1989, p. 26). But again, Leibniz assumes that the only requirements that have to be met in order for this to be true are (Consistency) and (Content) (he is not invoking 'moral possibility' in this context), whereas Kant thinks that even fundamental predicates can be 'really' rather than logically incompatible. Kant criticizes Leibniz in both pre-critical and critical writings for this. 
being that exemplifies all of the non-gradable fundamental predicates and all the maximal predicates together could play the grounding role for all really possible and mutually harmonious fundamental and maximal predicates. In other words, if an ens perfectissimum is really possible, then the (unique) ens perfectissimum exists. I submit this tentatively as a suggestion that is not found in Kant's texts, but may still be the best argument available to him in support of (11).

\section{Constructing derivative predicates: the first Spinozistic threat}

So far we have seen that it is necessary, according to Kant, that the content and harmony of the fundamental predicates and the maximal predicates be grounded in a unique actual being. But recall that Kant also claims that many really possible predicates need not be exemplified at all, as long as they can be 'constructed' from fundamental predicates that are exemplified by that being. ${ }^{33}$ This construction takes place via operations of combination, negation, and what Kant calls 'limitation'. Thus, for example, the positive predicate having thought as exemplified in reality can, by way of simple negation, ground the real possibility of the negative predicate not having thought. Likewise the exemplification of the maximal predicate being omniscient can, by way of limitation, ground the real possibility of the exemplification of the 'limited' predicate having some knowledge. I have been calling any predicate that can be constructed in this way a derivative predicate. Maximal predicates, being the highest on their respective gradable continua, are presumably derivative in this way, though we have encountered other reasons to think that God, for Kant, must exemplify them.

What about a predicate like being extended? Kant suggests at one point in $O P B$ that it is fundamental - that it is positive and unanalysable $(2: 80)$. But if that is so, then the logic of the proof makes it necessary that some actual being exemplifies it, or at least its maximal counterpart - namely, being infinitely extended. This provides the first inkling that something like Spinozism falls out of the proof, and it

33 'Such a being is, therefore, the most real of all possible ones, for all other beings are only possible through it alone. But this is not to be understood to mean that all possible reality is included among its determinations. This is a conceptual confusion that has been remarkably prevalent until now. People accord all realities to God or the necessary being indiscriminately as predicates, without noting that these predicates can by no means co-exist together as determinations in a single subject' $(2: 85)$. 
may be Kant's implicit realization of this that makes him lurch, suddenly, into apparent self-contradiction. Just a few pages after the suggestion that extension is a fundamental predicate, he abruptly claims that 'the impenetrability of bodies, extension, and the like could not be predicates of [God]' because God 'has understanding and will'. If the former were predicates of God, says Kant, then the divine essence would contain a 'real repugnance or positive conflict of its own determinations ... which would contradict its maximum reality' (2:86). Kant just asserts this here, without noting that his earlier suggestion about the fundamentality of extension suggests just the opposite. $^{34}$

In the critical period, Kant drops without fanfare the suggestion that extension is fundamental:

I cannot ascribe extension to God as a predicate, because it is only a concept of sense, and if I separate everything negative from it, nothing real at all is left over. Similarly, after I remove everything negative and sensible from the concept of matter, I retain nothing but the concept of an externally active power. And in the case of the concept of spatial presence, if I leave out the condition of sense (i.e. space), nothing but the pure reality of presence is left over. From these concepts, therefore, I will be able to apply to God only the realities themselves: power and presence. (Lectures on the Philosophical Doctrine of Religion 28:1021-2) $)^{35}$

The first sentence here is really an overstatement, since throughout the critical period Kant will say that there is a positive character to space as the form of outer, sensible intuition, and not that it is wholly 'negative'. It is true, however, that pure extension is just the form and not the 'matter' of sensation: the latter is provided by way of things-in-themselves affecting the perceiving mind. Perhaps this is what Kant means when he says that when the 'form' of extension is abstracted from matter itself, all that is left is the concept of an active power - something that God could possess.

In any case, there is a clear hint in this passage that one of the things that drove Kant to idealism about extension in the critical period is an attempt to avoid ascribing that predicate to the most real being.

${ }^{34}$ It seems possible, as a result, that Kant may be characterizing someone else's view and not one that he actually meant to endorse. The context certainly does not make that clear, however.

35 Compare the 'On a Discovery' essay from 1790: '[T]he objects as things-in-themselves give the matter to empirical intuitions (they contain the ground by which to determine the faculty of representation in accordance with its sensibility), but they are not the matter thereof' (8:215). 
There is more than a hint of that in a key passage from the second Critique:

If the ideality of time and space is not adopted, nothing remains but Spinozism, in which space and time are essential determinations of the original being itself, while the things dependent upon it (ourselves, therefore included) are not substances but merely accidents inhering in it. (5:102)

The context of this passage makes it clear that Kant is worrying about 'creation' theories according to which God is not in time or space but still somehow creates and sustains things that are, in themselves, in time and space. That was effectively his pre-critical position, but in the critical writings he seems to think that it leads to Spinozism. So Kant clearly associated the adoption of transcendental idealism with the avoidance of Spinozism. ${ }^{36}$

Whatever Kant's actual motives, however, the Spinozistic conclusion can be avoided without going idealist about space. For on the (Leibnizean) relationalist view of space that Kant held in this period, extension and location can be analysed into predicates involving various powers to change the direction and speed of a moving body at a certain place, exclude a body from a certain part of space, and so forth. And these fundamental powers will of course be among the attributes of an omnipotent being. ${ }^{37}$

The problem really arises for Kant in 1768 , then, when he decisively rejects relationalism about space in favour of a variety of Newtonian absolutism. ${ }^{38}$ The latter doctrine, combined with the theistic proof in $O P B$, seems again to lead to a maximally extended ens realissimum - a conclusion that, as we have seen, Kant repeatedly and disapprovingly associates with Spinoza. ${ }^{39}$ In light of this, it is telling that only two

\footnotetext{
${ }^{36}$ For more on this issue, and on these passages in the second Critique, see Brewer and Watkins 2012.

37 Likewise, it was quite common among the Scholastics to analyze a predicate like being present in place $p$ in terms of the power to produce various effects at $p$. Thus omnipresence would also be analysed in terms of powers (see Aquinas $1265-74$, ST I, 8, 2-3). In the quotation above Kant does not go this far; he seems to leave 'the pure reality of presence' as one of the unanalysable predicates, but he does not say what this would amount to.

${ }^{38}$ See 'On the Basis of the Difference of Regions of Space' (1768) in Akademie vol. 2. Kant cites arguments by Euler there against Leibniz's relationalism, and also employs his 'incongruent counterparts' argument on behalf of absolutism for the first time, though without the further move to transcendental idealism. For sustained discussion see Buroker 1981.

39 Newton's view is that space is an 'emanative effect of God', and thus that omnipresence is genuinely substantive rather than virtual. In other words, for Newton space is an attribute of
} 
years later (in the 1770 Dissertation), Kant once again abandons absolutism about space conceived realistically - not in favour of a return to relationalism, but rather in favour of his own idealist view of absolute space and time - namely, transcendental idealism. The threat of Spinoza appears to have been dealt with, at least for the time being. We will see at the end of the paper, however, that the threat arises again for the critical Kant in a slightly different but far less exorable way.

For now, it is simply worth noting that, in addition to extension, there may be other predicates possessed by real possibilia that are fundamental (unanalysable and positive) but also incompatible with the traditional concept of God and God's attributes. Being in time comes to mind in this regard - again, presuming, as Kant did in the late 1760 , an absolutist view of time. We might also wonder about the kind of qualities mentioned above - for example, having phenomenal red as a quality of consciousness, being in pain, feeling hungry to such-and-such a degree, fearing that one will suffer a mid-life crisis at forty, and the like. Classical theologians are reluctant to ascribe such predicates to the Supreme Being, and yet they cannot obviously be analysed into some other more fundamental ones. Kant himself does not address this, but it seems that a fully worked-out model of God as the material ground of all possibility would have to show either that the predicates in question actually are analysable into predicates consistent with the traditional perfections or modify our conception of what sorts of predicates fit into the divine nature. Whether this could be done within the bounds of anything like monotheistic orthodoxy is a very open question.

\section{Necessary existence and personality}

Kant is explicitly committed throughout $O P B$ to the claim that

(12) ER exists necessarily [(11), sub-argument below]

But he needs an argument for this premiss, since the de dicto necessity that there be an ens realissimum does not ensure that the individual that plays that role in one world plays it in other worlds as well.

God - the 'divine sensorium' - and so God is literally present to every object in space (see Newton's De Gravitatione in Janiak 2004, p. 22). In the Religion, Kant blandly rejects this view of God's spatiality as a 'contradiction' and prefers to take Newton to have been offering a 'sublime analogy' to God's role as creator (6:138-9). 
In other words, Kant needs to avoid the fallacy of simply jumping from 'necessarily something exists' to the claim that some particular thing, $E R$, exists necessarily. And obviously it is important, given the goal of proving the existence of something like the classical God, to arrive at a de re necessary being, and not just a necessary truth about some being or other.

Kant does not give us non-question-begging help here. At risk of anachronism, however, it is worth noting that one way to move from de dicto to de re necessity is to argue from the predicate of worldmembership itself, or perhaps from predicate-possession-at-a-world. Starting with the former, consider the following sub-argument:

(a) Existing at each world is a maximal predicate [Premiss]

(b) Necessarily, ER exists at each world [(a), (11)]

(c) $E R$ is a necessary being [(b), definition of 'necessary being']

The thought behind (a) is that world-membership itself is a gradable predicate - an individual can exist in many worlds, or very few, or just one, and so forth. Thus it admits of a maximal version - namely, membership in, or existence at, each and every possible world. Since (11) says that $E R$ has all the maximal predicates, perhaps Kant could use something like this argument to get to (12).

An alternative route involves construing existing at world $_{n}$ as a fundamental predicate, and then using (11) to claim that $E R$ has this predicate with respect to any possible world $n$. The predicate existing at each possible world would just be the complex conjunction of all the fundamental predicates of the form 'existing at world,', and so this version of the argument would likewise deliver the necessary existence of $E R$. Those who, like Kant himself, reject the idea that existence is a 'real' or 'proper' predicate will probably prefer to use the relation of 'absolute positing' instead - that is, the relation that holds between a concept and an object at a world $(2: 73) .{ }^{40}$ On this construal, the predicate existing at world ${ }_{n}$ would just be shorthand for the relational predicate having its concept instantiated at world ${ }_{n}$. The maximal version of that predicate is thus having its concept instantiated at each world. Unless there is reason to think that instantiation relations

\footnotetext{
$4^{\circ}$ Kant remarks in $O P B$ that 'when existence occurs as a predicate in common speech, it is a predicate not so much of the thing itself as of the thought which one has of the thing' (2:72).
} 
also fail to be real or 'proper' predicates, this could provide another argument for the necessary existence of $E R .^{41}$

A final way to go would avoid existence predicates altogether and instead ascribe some other fundamental predicate, call it G, to some possible object at world $n$. Being $G$ at world $_{n}$ would then be the fundamental predicate that ER has, given (11), and this could easily be extrapolated (mutatis mutandum) to all possible ns. Given the assumption that having a predicate at a world involves existing at that world, ER would exist at each world and thus be a necessary being.

In sum: unless there is reason to think that not only existencepredicates but also instantiation relations and world-indexed predicates in general are not proper (real) predicates, it looks like there may be a number of routes to a conception of $E R$ as having a predicate at each world, and thus as existing necessarily.

The argument continues with the premiss that

(13) Necessarily, ER is immutable and eternal

Kant takes this to follow from premisses that he has already proved: that the being in question is maximally perfect and unique, and that it is the material ground of all other possibilities. Any change in such a being would have to involve a change in some of its predicates, but if it materially grounds all real possibilities, including those with maximal predicates, then its own predicates will be necessarily and 'thoroughly determined' in a particular way. In other words, such a being will be metaphysically required to have all of the predicates that it has, and to have them in a permanent and unchanging way. Thus, it is not possible for it to be in any way other than it actually is ... Its non-existence is absolutely impossible, so also its generation and decay; accordingly, it is eternal' (2:85). Clearly, if we grant that Kant has proved the doctrines on which (13) is premised, we will not find (13) itself very problematic.

Kant's argument on behalf of the final premiss that

(14) Necessarily, ER possesses understanding and will

starts with the claim that 'understanding and will and all reality of a spiritual nature' are 'true realities' that are predicated of possible

${ }^{41}$ There may be Bradleyan worries here. If instantiating a concept is a real predicate, and thus a real relation, then an object that instantiates the concept $\mathrm{C}$ will also instantiate the concept of 'instantiating C' and thus the concept of 'instantiating the concept of instantiating $\mathrm{C}^{\prime}$ and so on. It is not clear to me whether this regress is vicious. 
things. It is supposed to be obvious that these fundamental predicates - the ones that constitute mind (Geist) — 'may stand together with the maximum possible in a thing'. In other words, they are in harmony with one another and with the other maximal predicates that we ascribe to the necessary being (2:87). Kant's considered view, as we have seen, is that they are not in real harmony with predicates like being embodied, being extended, and the like. But of course, such physical predicates can be constructed as derivative 'consequences' of the divine predicates, rather than as predicates of the divine nature themselves. The predicates of mind, on the other hand, cannot be constructed from other predicates of the maximal being, and 'we can conceive no reality that could be substituted to make up the deficiency in a being which lacked them' (2:87-8). Thus, by the argument above, the ground of all real possibility must actually exemplify them together. ${ }^{42}$

Having shown that there is a unique being which materially grounds all real possibility by possessing all fundamental and maximal predicates, and having further shown that this being is necessary, immutable, eternal, and a conscious agent, Kant concludes that, given the classical conception of God,

(15) Necessarily, ER is divine (and thus: God necessarily exists). [(11)-(14), Kant's conception of 'God']

\section{Transcendental idealism and the second Spinozistic threat}

We have now seen that Kant's pre-critical possibility proof can be reconstructed as valid, albeit with some highly controversial premisses. The Grounding Premiss in (4) and its application to fundamental non-gradable as well as maximal predicates in (9) is perhaps the most controversial; I have tried to highlight both the benefits and costs of accepting it. I have also emphasized the importance of Kant's introduction of the logical/real modality distinction into Leibniz's version of the proof, and noted that at one crucial juncture this difference threatens to take Kant away from classical monotheism and towards an account on which the predicate being maximally

${ }^{42}$ At 2:88 Kant suggests that having understanding and having will are not only fundamental predicates but also gradable predicates that admit of a maximal version: 'understanding and will are properties which are capable of the highest degree of reality'. So perhaps there is an independent argument via maximality that would take us from (11) to (14). 
extended is exemplified by the Supreme Being. Finally I have claimed that Kant can avoid that implication in the critical period by adopting the view that space is not relational in the Leibnizean fashion, and not ultimately real in the Newtonian fashion, but rather that it is a non-relational, ideal form of our sensible intuition.

This would be a nice place to end the story. In this section, however, I will argue that a slightly different form of the Spinozistic threat cannot be so easily dispatched, even in a transcendental idealist context. Recall that Kant's official position is that the ens realissimum need not exemplify more than the fundamental predicates and the maximal predicates in order to ground all real possibility. That is because the other, derivative predicates and possibilities can be 'constructed' from them by appeal to combining, limiting, and negating operations. But given the distinction between logical and real modality, and given the argument from (Harmony) that was used to motivate (11), I submit that there is reason to think that God has to ground not just the fundamental and maximal predicates and the harmony between them, but also the harmony between constructed, derivative predicates as well. And that in turn implies that God must actually exemplify all the derivative predicates, too.

In order to see this point clearly, consider once again the predicate being extended, and assume with the critical Kant that it is a derivative predicate that can be analysed in terms of powers (28:1021-2). God's omnipotence thus allows Him to be the material ground of the real possibility of an extended thing. Now consider the predicate being impenetrable, and suppose that it too is a derivative predicate constructed from various fundamental powers which are materially grounded in omnipotence. In $O P B$, Kant assumes that these two facts - that God can ground the real possibility of an extended thing, and that God can ground the real possibility of an impenetrable thing - entail that God can ground the real possibility of an extended impenetrable thing too.

But is this correct? Given what was said above about real harmony and real repugnance, and given the fact that the modal status of the fundamental predicates together with the rules for 'construction' are not sufficient to explain the modal features of the derivative predicates, will the ground of all real possibility not also have to ground the harmony between these two derivative predicates - that is, the harmony between being impenetrable and being extended? And will grounding that harmony not require that God actually exemplify both of these predicates together somehow? The answer to these 
two questions appears to be 'Yes'; otherwise, for all we know, the very process of constructing impenetrability or extension from fundamental predicates may give rise to a repugnance that makes an impenetrable extended thing really impossible. In order to avoid this, God's full being rather than His mere powers must be part of the ground of the real harmony between the derivative predicates too.

The example involves physical predicates that (someone might worry) are not ultimately real in an idealist context, and whose real harmony may thus be grounded in the determinations of the noumenal entities responsible for the empirical apprehension of extended, impenetrable things. So let us consider two predicates that do not raise this sort of worry: being free and being radically evil. Kant explicitly thinks of these as positive predicates that have real content and attach to certain noumenal beings. While the former is a fundamental predicate, the latter is taken by Kant in the Religion to be analysable into more fundamental predicates such as having a predisposition towards the good, having a propensity towards the bad, siding with the bad propensity over the good predisposition, and so forth. But how is the real possibility of a radically evil will supposed to be materially grounded? The discussion above indicates that the ground of all possibility must exemplify not just the fundamental predicates out of which radical evil is constructed (that would already be unattractive from a classical theological point of view, of course!), but also the derivative predicate being radically evil itself, in conjunction with the fundamental predicate being free. For only this fact - that they are already exemplified together in a single being — is able in Kant's view to ground the fact that these two predicates can be exemplified together. The actualist orientation of the proof comes out very clearly here: the only suitable explanation we have of why two particular predicates (be they fundamentals or derivatives) really can be co-exemplified is that they really are co-exemplified.

A converse kind of issue arises when we consider the predicates being $A u$ and being water. Let us assume that these are not fundamental predicates; each is constructed out of more fundamental predicates that God instantiates (in the case of being $A u$, these would presumably be powers to constitute the electron shell and the electron configuration in a particular way). Those fundamental predicates are compatible, but being $A u$ and being water are really repugnant; thus the repugnance must somehow be arising from the very derivation process itself. In other words, the power to produce an empirical substance that is water and the power to produce a substance that has the 
chemical composition $\mathrm{Au}$ are both powers that God presumably does have, but the complex power that results from simply combining these two - namely, the power to produce a substance that is both water and has the chemical composition $\mathrm{Au}$ - is one that not even God has. But why is that? There is no logical contradiction between the two (assuming that we are using a non-technical concept of water), and the simple operation of 'combining' does not explain the impossibility of the combination. So we need some further explanation of why the two derivative predicates being water and being $A u$ turn out to be really repugnant. Clearly an appeal to God's omniscience will not suffice here, just as it will not suffice to ground the harmony of being water and being $\mathrm{H}_{2} \mathrm{O}$. That is because God's omniscience itself needs an explanation - or, more precisely, the fact that these are some of the propositions that God knows about water needs an explanation. Unlike Leibniz, Kant is not willing to leave such facts unexplained: as we have seen, he thinks God's knowledge of such 'real essences' must be grounded in the non-intentional properties of the divine nature. So the incompatibility of predicates like being water and being $A u$ must be grounded in the fact that they are not actually exemplified together in the most real being, while the compatibility of being water and being $\mathrm{H}_{2} \mathrm{O}$ is explained by the fact that they are so exemplified. (And why is that? Here is where Kant's spade is finally turned: they just are. However, if an actualist is going to turn his spade somewhere, it seems as though the non-intentional predicates of a necessary, Supreme Being is a very good place to do so. ${ }^{43}$ )

Note that the real possibility of predicates such as being able to co-exist with $A u$ or being able to prevent co-existence with $A u$ is not at issue here. Those predicates can presumably just be grounded in divine power. Rather, the issue is how particular facts about which pairs of predicates are harmonious and which pairs are repugnant can be explained within Kant's rationalist-actualist picture. In particular, we still need an explanation of why water has that power - especially if the fundamental predicates out of which both being water and being $A u$ are constructed are themselves harmonious. God's power may be able to explain the fact that repugnance and harmony relations are really possible in general, but all by itself it does not ground particular

\footnotetext{
${ }^{43}$ Leibniz's explanatory spade is turned in this region, too, though his claim is that the being and content of the essences are grounded in divine thought rather than in actual exemplification. For discussion, see Newlands MS. For further discussion of why Kant's way of grounding these fundamental facts might be superior, see Adams 2000.
} 
facts about which predicates bear which relations to which other predicates. ${ }^{44}$

Summarizing this point very generally: suppose that some complex derivative predicate $\mathrm{A}$ is constructed from the conjunction of fundamental predicates $\mathrm{F}$ and $\mathrm{G}$, and that some other derivative predicate $\mathrm{B}$ is constructed from the conjunction of fundamental predicates $\mathrm{H}$ and J. Even if F, G, H, and J are really harmonious and thus able to be exemplified together in the divine nature, that still does not guarantee that the derivative predicates $\mathrm{A}$ and $\mathrm{B}$ are really harmonious (or that A is really harmonious with $\mathrm{H}$ and/or J, and so on). That is because, again, repugnance may arise from the very process of construction or derivation itself. And the facts concerning when it does and when it does not will also require a ground in the most real being.

The conclusion may seem odd given that the derivations themselves occur via simple logical operations like 'limitation', 'combination', 'negation', and the like. But that is precisely Kant's point against Leibniz in the pre-critical period, as well as in later work such as the 'Amphiboly' chapter of the first Critique. Such operations, when brought into an extra-logical, metaphysical context by being applied to real predicates or natures, produce results that general logic does not predict. ${ }^{45}$

If the point I am making here is correct, then it clearly will not do for the ens realissimum merely to exemplify all of the non-gradable fundamental predicates and all of the maximal predicates. Rather, all really possible predicates have to be exemplified in such a way that all of the facts about all of the ways in which these predicates are mutually really harmonious are also materially grounded. And as a result, the necessary being that Kant's proof delivers begins once more to look like Spinoza's God - a being that exemplifies all absolutely really possible predicates together - and quite different from the immaterial, invisible spirit-God of classical theism. ${ }^{46}$ The argument also suggests

44 Thanks to the editor of Mind for questions that led me to clarify these issues.

45 Note in this connection that Kant distinguishes in the 'Ideal of Pure Reason' chapter in the Critique between 'logical negation' and what he calls 'transcendental negation'. Kant makes it clear there that he thinks the metaphysical analogue of a simple logical operation like 'negation' often exhibits more complex behaviour than the latter, given the nature of the predicates to which it is applied.

$4^{6}$ See Spinoza's Ethics 1p33: 'Things could have been produced by God in no other way and in no other order than they have been produced' (Spinoza 1677; Curley 1985). This suggests that everything that is really possible exists, and that everything that is not actual is impossible-i.e. necessitarianism. But even if the actual Spinoza was not a necessitarian (this is somewhat controversial), the 'Spinoza' discussed by eighteenth-century German participants in the Pantheismusstreit certainly was. 
that there will be massive logical and real repugnance in the divine nature, since, as we have seen, some of these positive predicates that are really possible per se are not mutually harmonious!

Perhaps this second consequence can be avoided by positing a kind of furcated structure in the divine nature such that any two predicates that are logically inconsistent or really repugnant inhere in causally and explanatorily distinct aspects of it. The Spinozistic term for such furcations, of course, is 'attributes'. On such a view, the real harmony between two or more positive predicates is explained by the fact that they are modes of the same attribute of God, and the real repugnance between two or more predicates is explained by the fact that they do not modify the same attribute. But this implies that the most real being has to possess a huge or perhaps infinite number of such attributes in order to do all of the explanatory work, and that most of the fundamental predicates have to be multiply-instantiated across numerous divine attributes. ${ }^{47}$ Naturally, none of this is actually contemplated by Kant, and in $O P B$ as well as his final aphoristic writings he scorns anything like the 'enormous' Spinozistic idea of God (2:74, cf. Opus Postumum 21:50). It may be, however, that malgré lui Kant's own proof of God's existence leads to something just as enormous. ${ }^{48}$

\section{Conclusion: harmony, repugnance, and Spinoza}

I have argued that by 1770 - after Kant had decisively rejected relationalism about space - he was effectively faced with the following inconsistent quartet:

(i) The argument in $O P B$ is sound

(ii) God is not extended in space or time

(iii) Thought tracks logical possibility, intuition tracks actuality

(iv) Space and time are objective, absolute entities

${ }^{47}$ It may also threaten the argument for divine uniqueness above, which was grounded in the need for a single (and presumably non-furcated) ground of real harmony. Thanks to Peter Yong for making this point to me in discussion.

${ }^{48}$ Note that if what is said here is correct, Kant's proof would require the explanatory distinctness or 'barrier' between the attributes, but not Spinozistic parallelism or identity between their modes. It was common for early modern thinkers to accuse a view of Spinozism even if it lacked the parallelism doctrine. See for instance, Sukjae Lee's discussion of Leibniz's accusation that Malebranche is a Spinozist (MS). 
Kant remained committed to (i) throughout his career, ${ }^{49}$ though he changed his mind in 1781 about the epistemic status of the proof's conclusion. Given the reconstruction above, (i) in conjunction with (iii) and (iv) leads to the negation of (ii) by way of proving the existence of an extended, temporal deity that has to exemplify all the other positive predicates as well. That is a conclusion that Kant (and other German philosophers at the time) regularly associated with Spinoza, and which he almost certainly considered anathema. So either (iii) or (iv) has to go.

(iii) is asserted most clearly in the B-Preface to the Critique: 'I can think whatever I like, as long as I do not contradict myself ... [but] I cannot give any assurance whether or not there is a corresponding object somewhere within the sum total of all [real] possibilities. But in order to ascribe objective validity to such a concept (real possibility, for the first sort of possibility was merely logical) something more is required' (Bxxvi, note). So, in the critical period, Kant is clearly committed to the thesis that thought tracks merely logical possibility, whereas something else is required in order to know whether something is really possible. Already in the 'Negative Magnitudes' essay of 1763 , however, we are told that a logically incoherent concept is 'a negative nothing, not able to be represented (nihil negativum irrepraesentabile)', whereas a concept that contains real repugnance is still 'thinkable' (cogitabile). In other words, 'the result of the [real] opposition is also nothing, but nothing in another sense than that in which it occurs in a [logical] contradiction'. It is 'a privational nothing, able to be represented (nihil privativum, repraesentabile)' in mere thought, whereas a logical opposition is not (2:171-2).

This point about discursive thought — that it reliably tracks logical and not real possibility — is presumably true quite generally, and not just with respect to human modes of thinking. The thought of a complex object - for example, an extended, impenetrable being — may be sufficient to guarantee that its predicates are logically consistent and possessed of real content, and this of course was what concerned Leibniz. But for Kant even divine thought will not be enough to guarantee real harmony and thus the relevant sort of real possibility. That is simply not what thinking (Denken) does..$^{50}$

49 See for example 28:1034, 18:545, and other passages discussed in Chignell 2009a.

50 The point about 'reliable' tracking is important, since Kant's discussion of subjectcancelling real repugnance presumes that we are sometimes able (in paradigm cases) to see that a concept is afflicted by it. The point in this section is that we have no faculty that reliably 
Having noted that divine thought cannot serve as a material ground of real possibility, it is also worth noting that this may be of little consequence, since Kant's God does not really think at all (B71; cf. 1:405). Thought is by definition discursive - it involves concepts - and although we have seen that Kant often anthropomorphizes and ascribes conceptual knowledge, cognition, and understanding to the supreme being (cf. $2: 30-1,72,76,88,90$ ), his official view is that the mind of the ens realissimum contains no thoughts and does not reason. Conceptual, rational thought is a welcome feature of our minds, but it reflects our finite status all the same. It would be unfitting for the most exalted mind to engage in the generalizing, approximating, and running-through of content that is involved in concept-application; instead, God is aware of every detail of reality immediately in what Kant calls intellectual intuition.

Even granting this, however, it should be clear that Kant is no more able to appeal to divine intuition as the ground of real possibility than he is able to appeal to divine thought. Unlike human sensible intuition, intellectual intuition cannot be receptive, since any sort of receptivity or passibility is also incompatible with supreme perfection. Instead, the divine mental act is a singular, productive representation of the entire world-whole, an apprehension for which there is neither possibility nor necessity (5:402-3). In other words, the intellectus archetypus intuits every individual thing, but only in virtue of simultaneously creating and conserving it as part of the created whole (B72, B145, Critique of Judgement \$76-\$77; Lectures on Religion 28:1051). Claiming that every possibility — Falstaff, a winged giraffe, a hippogriff, etc. - exists as a part of the created world would lead to a monstrously rich ontology that is quite out of keeping with Kant's overall picture. In order to avoid this, there would need to be a mind that represents objects in a way that grounds their real possibility but does not ipso facto guarantee their actuality. Another way to put this is to say that we need a mind that reliably represents in the 'real problematic mode', where 'problematic' refers to merely possible things, and 'real' refers to real possibility. But in the Analytic of the first Critique, Kant rules out any such mode of judging: the 'problematic' mode explicitly refers to logical possibility and the 'assertoric' mode refers

tracks which of the logical possibilities are really possible and which are really impossible. And neither, surprisingly enough, does the most real being. 
to actuality (A75/B101). There is nothing in between..$^{51}$ Moreover, if God were able to produce real possibilities without making them actual, then we would end up with a quasi-voluntarist view of the sort that Kant eschewed: divine intuition would somehow be causing or producing possibility rather than merely tracking independent modal facts. ${ }^{52}$

So, again, our thoughts and intuitions do not reliably track real possibility, and divine perfection requires that all the objects of God's unique productive intuition are actual. (iii) is thus surprisingly hard to resist: there is simply no mind in Kant's ontology that can reliably represent objects in a 'real' but still 'problematic' mode, and thus no kind of representation that can ground facts about real possibility simply in virtue of taking them as its objects.

The only other way out of the inconsistent quartet, of course, is to reject (iv) and go idealist about space and time such that 'being extended' and the like are no longer conceived as fundamental predicates. On this view, extension together with its modes is a phenomenal result of the transaction between things-in-themselves and perceiving minds, and since those things and those minds are not themselves extended they can unproblematically find their ground in the predicates of the classical deity. It should be clear that this is the route that the historical Kant actually took.

The final part of our story, however - the part which Kant did not seem to notice - is that the threat of Spinozism returns when we consider how the real harmony of non-fundamental or derivative predicates (with one another, and with the fundamental predicates) is grounded. It is unclear in light of his own argument how Kant could avoid appealing to God as the ground of this harmony, and it would seem that God could only do that by actually exemplifying all possible predicates - fundamental and derivative - as modes of an infinite array of explanatorily distinct divine furcations or attributes. With respect to this second Spinozistic threat, transcendental idealism is impotent.

\footnotetext{
${ }^{51}$ Marleen Rozemond points out in conversation that this means that Kant's God cannot have chosen between possible worlds when creating, or have surveyed various non-actual possibilities, if God's mind was not intuiting in a 'real problematic' mode. In the early part of the pre-critical period, Kant does speak in these ways, but his considered view seems to push him in the direction of an 'emanation' picture of creation (which is of course very Spinozistic). For more on this, see Kain forthcoming.

52 This point goes unappreciated by Stang (2010) in his discussion of the proof.
} 
So, (Harmony) is Kant's real innovation over Leibniz - (Harmony) is what drives Kant's version of the proof from possibility. But given his entrenched commitments about the nature of thought and his view of the logical/real modality distinction, (Harmony) also threatens to transform the necessary being delivered by Kant's proof into an 'enormous' being that contains all really possible predicates, in all of their possible combinations, as modes of an infinite number of related or explanatorily distinct attributes.

It has been suggested more than once that all rationalist roads lead to Spinoza's door, ${ }^{33}$ if the argument here is correct, then even Kant's critical rationalism is no exception to the rule. ${ }^{54}$

\section{References}

Abaci, Uygar 2011: 'Kant's Critical Theory of Modality: A Basis for Moral Metaphysics'. Dissertation at the University of Pennsylvania.

Adam, Charles and Paul Tannery (eds) 1996: Oeuvres de Descartes. Paris: Vrin. [Referred to above as 'AT'.]

Adams, Robert M. 1994: Leibniz: Determinist, Idealist, Theist. New York: Oxford University Press.

2000: 'God, Possibility, and Kant'. Faith and Philosophy, 4, pp. 425-40.

Allison, Henry 2004: Kant's Transcendental Idealism, second edition.

New Haven: Yale University Press.

Aquinas, Thomas 1265-74: Summa theologiae. In Caramello 1948.

Armstrong, David M. 1997: A World of States of Affairs. New York: Cambridge University Press.

Baldwin, Thomas 2002: 'Kantian Modality'. Aristotelian Society Supplementary Volume 76, pp. 1-24.

Baumgarten, Alexander 1779: Metaphysica, second edition. Halle: Hemmerde.

53 In Kant's own day by Jacobi (1787) and, much more recently, by Della Rocca (2003).

54 I am grateful to the following people for helpful comments and feedback on this paper: Uygar Abaci, Robert Adams, Omri Boehm, Kimberly Brewer, Don Garrett, Harold Hodes, Desmond Hogan, Thomas Hofweber, Anja Jauernig, Patrick Kain, Sam Newlands, Derk Pereboom, Ian Proops, Marleen Rozemond, Nick Stang, Eric Watkins, Kenneth Winkler, Allen Wood, Peter Yong, and the referees and editor of Mind. I also profited from discussions of these ideas at Toronto, Yale, Notre Dame, UNC-Chapel Hill, and Johns Hopkins. 
Beck, Lewis White 1956: 'Kant's Theory of Definition'. Philosophical Review, 65, pp. 179-91.

Boehm, Omri forthcoming: 'Kant's Idea of the Unconditioned and Spinoza's'. In Melamed forthcoming.

Brewer, Kimberly and Eric Watkins 2012: 'A Difficulty Still Awaits: Kant, Spinoza, and the Threat of Theological Determinism'. Kant-Studien, 103, pp. 163-87.

Buroker, Jill Vance 1981: Space and Incongruent Counterparts: The Origin of Kant's Idealism. Dordrecht: Reidel.

Caramello, Petri (ed.) 1948: St. Thomae Aquinatis, Summa theologiae: Cum textu ex recensione Leonina. Marietti: Torino.

Chalmers, David 2002: 'Does Conceivability entail Possibility?' In Gendler and Hawthorne 2002, pp. 145-200.

Chignell, Andrew 2007: 'Belief in Kant'. Philosophical Review, 116, pp. 323-6o.

2009a: 'Kant, Modality, and the Most Real Being'. Archiv für Geschichte Der Philosophie, 91, pp. 157-92.

- 2009b: 'Real Repugnance and our Ignorance of Things-inThemselves: A Lockean Problem in Kant and Hegel'. Internationales Jahrbuch des Deutschen Idealismus, 7, pp. 135-59.

2010: 'Real Repugnance and Belief about Things-in-Themselves: A Problem and Kant's Three Solutions'. In Krueger and Lipscomb 2010, pp. 177-209.

Cottingham, John, Robert Stoothoff, and Dugald Murdoch (eds) 1984: The Philosophical Writings of Descartes. New York: Cambridge. [Referred to above as 'CSM'.]

Crusius, Christian August 1743: Dissertatio de usu et limitibus principii rationis determinantis vulgo sufficientis. Leipzig: Gleditsch.

1745: Entwurf der nothwendigen Vernunft-Wahrheiten: wiefern sie den zufälligen entgegen gesetzt werden. Leipzig: Gleditsch.

Curley, Edwin (tr. and ed.) 1985: The Collected Writings of Spinoza, volume 1. Princeton: Princeton University Press.

Descartes, René 1641: Meditationes. In Adam and Tannery 1996.

Della Rocca, Michael 2003: 'A Rationalist Manifesto: Spinoza and the Principle of Sufficient Reason'. Philosophical Topics, 31, pp. 75-93.

Fisher, Mark and Eric Watkins 1998: 'Kant on the Material Ground of Possibility: From the Only Possible Argument to the Critique of Pure Reason'. Review of Metaphysics, 52, pp. 369-95. 
Gendler, Tamar Szabo and John Hawthorne (eds) 2002: Conceivability and Possibility. New York: Cambridge University Press.

Greenberg, Robert 2008: Real Existence, Ideal Necessity. Berlin: Walter de Gruyter.

Jacobi, F. H. 1785: Über die Lehre des Spinoza in Briefen an den Herrn Moses Mendelssohn. Breslau: Loewe.

-1787: David Hume über den Glauben, oder Idealismus und Realismus, Ein Gespräch. Breslau: Loewe.

Janiak, Andrew (ed.) 2004: Newton's Philosophical Writings. New York: Cambridge University Press.

Kain, Patrick forthcoming: 'The Development of Kant's Conception of Divine Freedom'. In Look forthcoming.

Kant, Immanuel 1902: Gesammelte Schriften, 29 volumes. Berlin: Königlich-Preussischen Akademie der Wissenschaften zu Berlin (now Walter deGruyter).

1979: The Only Possible Basis for a Demonstration of the Existence of God, tr. and ed. Gordon Treash. Lincoln: University of Nebraska Press.

1992a: Theoretical Philosophy 1755-1770, tr. and ed. David Walford and Ralf Meerbote. New York: Cambridge University Press.

1992b: The Only Possible Argument in Support of a Demonstration of the Existence of God, tr. and ed. David Walford. In Kant 1992a, pp. 107-201.

1998: Critique of Pure Reason, tr. and ed. Paul Guyer and Allen Wood. New York: Cambridge University Press.

Kopper, Joachim 1955: 'Kants Gotteslehre'. Kant-Studien, 47, pp. 31-63. Laberge, Pierre 1973: La Theologie Kantienne precritique. Ottawa: Laumier.

Lee, Sukjae MS: 'Why Bundles of Modes Are Not Substances: Leibniz's Criticism of Occasionalism as Spinozism'.

Leibniz, Gottfried Wilhelm 1849-63: Leibnizens mathematische Schriften, ed. Carl Gerhardt. Halle: H. W. Schmidt.

-1875-1890: Die philosophischen Schriften von G.W. Leibniz, ed. Carl Gerhardt. Berlin: Weidmann.

1969: Philosophical Papers and Letters, second edition, tr. and ed. Leroy Loemker. Dordrecht: Reidel.

1989: Philosophical Essays, ed. Roger Ariew and Daniel Garber. Indianapolis: Hackett Publishing Company. [Referred to above as 'AG'.] 
2005: Confessio Philosophi: Papers Concerning the Problem of Evil 1671-1678, tr. and ed. Robert Sleigh. New Haven: Yale University Press.

Look, Brandon (ed.) forthcoming: Leibniz and Kant. New York: Oxford University Press.

Melamed, Yitzhak (ed.) forthcoming: Spinoza and German Idealism. New York: Cambridge University Press.

Meier, Georg Friedrich 1752: Auszug aus der Vernunftlehre. Halle. Merricks, Trenton 2007: Truth and Ontology. New York: Oxford.

Newlands, S. MS: 'Leibniz and the Ground of Possibility'.

Newton, Isaac 1684-5: 'De Gravitatione et aequipondio fluidorum et solidorum in fluidis'. In Janiak 2004.

Pereboom, Derk 1991: 'Is Kant's Transcendental Philosophy Inconsistent?' History of Philosophy Quarterly, 8, pp. 357-72.

Pistorius, H. A. 1788: 'Critic der reinen Vernunft, von Immanuel Kant, Prof in Koenigsberg'. Allgemeine deutsche Bibliothek, 81, pp. 343-54.

Redmann, H-G. 1962: Gott und Welt: Die Schöpfungstheologie der vorkritischen Periode Kants. Göttingen: Vandenhoeck \& Ruprecht.

Schönfeld, Martin 2000: Philosophy of the Young Kant. New York: Oxford University Press.

Stang, Nicholas 2010: 'Kant's Possibility Proof'. History of Philosophy Quarterly, 27, pp. 275-99.

Wolff, Christian 1720: Vernünffige Gedancken von Gott, der Welt und der Seele des Menschen, auch allen Dingen überhaupt. In Wolff 1983, vol. 1, no. 2.

1983: Gesammelte Werke, ed. Charles Corr. Hildesheim: Olms.

Wood, Allen 1978: Kant's Rational Theology. Ithaca: Cornell University Press. 